\title{
Aplikasi Pupuk Organik Cair Urin Kelinci Meningkatan Pertumbuhan dan Produksi Caisim (Brassica juncea L.) Organik di Yayasan Bina Sarana Bakti, Cisarua, Bogor, Jawa Barat
}

\section{Rabbit Urine Fertilizer Application Increases Growth and Production of Organic Green Mustard (Brassica juncea L.) at Bina Sarana Bakti Foundation, Cisarua, Bogor, West Java}

\section{Dhedy Kristanto dan Sandra Arifin Aziz*}

Departemen Agronomi dan Hortikultura, Fakultas Pertanian, Institut Pertanian Bogor (Bogor Agricultural University), J1. Meranti, Kampus IPB Darmaga, Bogor 16680, Indonesia Telp. \& Faks.62-251-8629353 e-mail agrohort@apps.ipb.ac.id

*Penulis Korespondensi : sandra.a.aziz@gmail.com

Disetujui : 21 Mei 2018 / Published Online September 2019

\begin{abstract}
This research is held at Organic Garden of Bina Sarana Bakti Foundation (YBSB), Cisarua, Bogor, West Java. This apprenticeship activity aims to study the effect of the rabbit urine liquid organic fertilizer concentration on growth and yield of organic green mustard. Primary data were collected through an experiment using a Randomized Complete Group Design of 1 factor with 4 levels $(0,5,10$, and 15\%) rabbit urine and 3 replications so that there were 12 experimental units. The organic green mustard is combined with red lettuce with 3 rows of organic green mustard plants and 2 red lettuce lines on the right and left sides. Organic vegetable production activities in YBSB as a whole have gone well. This internship activity is able to increase knowledge and skill of writer both from technical and managerial aspect in organic vegetable cultivation. The application of rabbit urine liquid organic fertilizer significantly increases the growth of leaf number, leaf width and stem diameter of organic green mustard. Rabbit urine $10 \%$ is the best concentration to be applied to organic green mustard plant, that yielded the highest profitable marketable weight with a $72.87 \%$ increase.
\end{abstract}

Keywords: clubroot, eco-friendly, green mustard, vegetable, waste

\begin{abstract}
ABSTRAK
Kegiatan penelitian ini dilaksanakan di Kebun Organik Yayasan Bina Sarana Bakti (YBSB), Cisarua, Bogor, Jawa Barat. Kegiatan penelitian ini bertujuan untuk mempelajari pengaruh konsentrasi pupuk organik cair urin kelinci terhadap pertumbuhan dan hasil produksi sayuran caisim secara organik. Data primer diambil melalui percobaan menggunakan Rancangan Kelompok Lengkap Teracak (RKLT) 1 faktor dengan 4 taraf urin kelinci (0, 5,10 , dan 15\%) dan 3 ulangan sehingga terdapat 12 satuan percobaan. Tanaman caisim dikombinasikan dengan selada merah dengan letak 3 baris tanaman caisim dan 2 baris selada merah di sisi kanan dan kirinya. Kegiatan produksi sayuran organik di YBSB secara keseluruhan telah berjalan dengan baik. Kegiatan penelitian ini mampu meningkatkan pengetahuan serta keterampilan penulis baik dari segi teknis maupun manajerial dalam budidaya sayuran organik. Aplikasi pupuk organik cair urin kelinci pada 1 minggu setelah tanam nyata meningkatkan pertumbuhan vegetatif tanaman caisim diantaranya jumlah, daun, panjang daun, lebar daun dan diameter batang. Konsentrasi urin kelinci $10 \%$ adalah konsentrasi terbaik untuk diaplikasikan pada tanaman caisim. Konsentrasi ini nyata meningkatkan bobot basah dan bobot rompesan caisim yang dipanen. Meskipun secara statistik ketiga perlakuan konsentrasi tidak menunjukkan perbedaan yang nyata, namun konsentrasi POC $10 \%$ menghasilkan rataan nilai tengah bobot layak jual tertinggi dengan persentase peningkatan sebesar $72.87 \%$, sehingga dapat dijadikan sebagai pilihan terbaik karena lebih menguntungkan dari segi ekonomi.
\end{abstract}

Kata kunci: akar gada, limbah, ramah lingkungan, sawi hijau, sayuran 


\section{PENDAHULUAN}

Konsumsi sayuran organik belakangan ini telah menjadi tren di kalangan masyarakat Indonesia. Masyarakat mulai meminati sayuran organik karena sayuran organik diyakini bebas dari racun-racun kimia dan lebih ramah lingkungan. Peningkatan minat konsumsi masyarakat ini diikuti oleh berkembangnya produsen dan komoditas organik (Inawati, 2011). Aliansi Organis Indonesia (AOI) juga mencatat semakin meningkatnya jumlah produsen komoditas organik, demikian juga ragam komoditas organik yang dibudidaya, merk dagang organik, dan pemasok ke pengecer seperti super market dan restoran besar. Luas areal pertanian organik di Indonesia pada tahun 2007-2012 mengalami fluktuasi. Luas areal pertanian organik pada tahun 2007 hanya 40.970 ha. Peningkatan luas areal yang signifikan terjadi pada tahun 2008 menjadi 208.535 ha. Pertambahan luasan areal terus terjadi hingga tahun 2009 dan 2010 yaitu 214.985 ha dan 238.872 ha. Namun pada tahun 2011 dan 2012 luas areal mengalami penurunan hingga 225.063 ha dan 213.023 ha (AOI, 2013).

Salah satu komoditas yang diminati masyarakat Indonesia adalah caisim atau yang biasa dikenal dengan sawi hijau. Caisim (Brassica juncea L.) merupakan tanaman sayuran dengan iklim subtropis, namun dapat beradaptasi dengan baik pada iklim tropis. Caisim pada umumnya banyak ditanam di dataran rendah, namun dapat pula di dataran tinggi. Caisim tergolong tanaman yang toleran terhadap suhu tinggi (panas). Saat ini, kebutuhan caisim semakin lama semakin meningkat seiring dengan peningkatan populasi manusia dan manfaat mengonsumsinya bagi kesehatan. Rukmana (1994) menyatakan caisim mempunyai nilai ekonomi tinggi setelah kubis crop, kubis bunga dan brokoli. Tahun 2015 konsumsi caisim mencapai 532.37 juta kg kapita $^{-1}$ tahun $^{-1}$ dan mengalami peningkatan pada tahun 2016 menjadi 539.80 juta kg kapita ${ }^{-1}$ tahun $^{-1}$ (Departemen Kesehatan, 2017).

Produsen sayuran organik memerlukan pengetahuan dan keterampilan yang baik dalam proses budidaya agar produksi optimum dan berkelanjutan. Salah satu upaya dalam meningkatkan produksi tanaman adalah melalui penambahan unsur hara kepada tanaman melalui media tanam antara lain, melalui cara organik. Pertanian organik mempunyai filosofi mengembangkan prinsip memberikan hara pada tanah, selanjutnya tanah menyediakan hara untuk tanaman, dengan demikian bukan memberikan langsung kepada tanaman. Pemupukan organik bertujuan meningkatkan kesuburan dan kegiatan biologi tanah yang dilaksanakan dengan cara menambahkan bahan organik dalam jumlah yang cukup dan diupayakan berasal dari dalam petak pertanian itu sendiri (Sutanto, 2002).

Pupuk organik dapat dibuat dari pemanfaatan limbah peternakan atau sisa-sisa tanaman yang ada. Pupuk organik dapat berupa pupuk padat atau cair. Pupuk organik cair (POC) memiliki beberapa manfaat diantaranya membantu meningkatkan produksi tanaman, meningkatkan kualitas produk tanaman, mengurangi penggunaan pupuk anorganik dan sebagai alternatif pengganti pupuk kandang (Indrakusuma, 2000). Aplikasi POC urin kelinci merupakan salah satu alternatif dalam penerapan teknologi pertanian yang berwawasan lingkungan dan berkelanjutan. Urin kelinci dapat dimanfaatkan sebagai pupuk organik cair karena mengandung nitrogen, fosfor, kalium dan air lebih banyak daripada kotoran sapi padat. Aplikasi pemberian POC urin kelinci yaitu dengan cara disiramkan ke tanaman (Maspary, 2011).

Semakin tinggi dosis pupuk yang diberikan maka kandungan unsur hara yang diterima oleh tanaman akan semakin tinggi, begitu pula dengan semakin seringnya frekuensi aplikasi pupuk yang dilakukan pada tanaman, maka kandungan unsur hara juga semakin tinggi. Namun, pemberian dengan dosis yang berlebihan justru akan mengakibatkan timbulnya gejala kelayuan pada tanaman (Suwandi dan Nurtika, 1987). Oleh karena itu, pemilihan konsentrasi dan dosis yang tepat perlu diketahui oleh para peneliti dan hal ini dapat diperoleh melalui pengujian di lapangan. Kegiatan penelitian ini secara umum bertujuan untuk meningkatkan pengetahuan dan keterampilan penulis baik teknis maupun manajerial dalam kegiatan produksi sayuran organik, serta secara khusus untuk mempelajari cara pembuatan dan aplikasi POC dalam upaya meningkatkan pertumbuhan dan hasil produksi sayuran caisim.

\section{METODE}

Metode penelitian yang dilakukan mahasiswa meliputi serangkaian kegiatan budidaya sayuran organik yang dilakukan sesuai dengan jadwal yang telah ditentukan oleh pihak perusahaan.

Data primer diambil dari pengamatan kombinasi tanaman caisim dan selada merah yang diberikan perlakuan empat konsentrasi POC urin kelinci $(0,5,10$, dan 15\%) dengan tiga ulangan. Percobaan ini menggunakan Rancangan Kelompok Lengkap Teracak (RKLT) 1 faktor dengan 4 taraf dan 3 ulangan sehingga terdapat 12 satuan percobaan. Setiap petak/satuan percobaan berukuran $2.5 \mathrm{~m} \times 1 \mathrm{~m}$. Tanaman caisim dikombinasikan dengan selada merah, dengan letak 3 baris tanaman 
caisim dan 2 baris selada merah di sisi kanan dan kirinya. Caisim ditanam dengan jarak tanam $20 \mathrm{~cm} x$ $20 \mathrm{~cm}$, dan selada merah $25 \mathrm{~cm}$ x $25 \mathrm{~cm}$ sehingga dalam satu ulangan terdapat 36 tanaman caisim dan 20 tanaman selada merah. Keduanya ditanam secara zig-zag dengan tujuan untuk memaksimalkan perakaran tanaman dan perolehan cahaya matahari. Perlakuan aplikasi POC dilakukan pada saat tanaman caisim berumur 1 minggu setelah tanam (MST).

Pupuk organik cair urin kelinci dibuat dari komposisi perbandingan urin kelinci 1 1, EM 410 $\mathrm{ml}$ dan molase $10 \mathrm{ml}$. Ketiga bahan tersebut dicampur dalam jerigen dan difermentasikan selama minimal 14 hari. POC urin kelinci yang telah matang memiliki ciri-ciri bau yang tidak terlalu menyengat serta suhu yang sudah stabil. Setelah matang, urin kelinci ini diaplikasikan pada tanaman caisim yang berumur 1 minggu setelah tanam. Cara aplikasi POC yaitu terlebih dahulu dilarutkan dengan air sesuai konsentrasi $(0,5,10$ dan 15\%), kemudian disiramkan ke tanaman menggunakan gembor berukuran 10 L. Dosis yang digunakan 12.51 per petak ulangan. Aplikasi dilakukan ketika pagi hari untuk menghindari penguapan pada siang hari. Pada Tabel 1 dan dapat dilihat dosis hara unsur $\mathrm{N}, \mathrm{P}_{2} \mathrm{O}_{5}$ dan $\mathrm{K}_{2} \mathrm{O}$ yang diberikan per tanaman.

Tabel 1. Dosis hara unsur N, P, dan K yang diberikan per tanaman

\begin{tabular}{lccc}
\multirow{2}{*}{ Dosis Hara } & \multicolumn{3}{c}{ Konsentrasi $(\mathrm{g})$} \\
\cline { 2 - 4 } & $5 \%$ & $10 \%$ & $15 \%$ \\
\hline $\mathrm{N}$ & 0.008 & 0.016 & 0.023 \\
$\mathrm{P} 2 \mathrm{O} 5$ & 0.001 & 0.002 & 0.003 \\
$\mathrm{~K} 2 \mathrm{O}$ & 0.088 & 0.176 & 0.265 \\
\hline
\end{tabular}

Keterangan: Berdasarkan gasil uji di Laboratorium Pengujian Departemen Agronomi dan Hortikultura, Fakultas Pertanian, IPB, POC urin kelinci yang digunakan mengandung $0.07 \% \mathrm{~N}, 0.01 \% \mathrm{P} 2 \mathrm{O} 5$, dan $0.79 \% \mathrm{~K} 2 \mathrm{O}$.

Pengamatan vegetatif dilakukan setiap minggu dan ketika panen dengan 10 tanaman sampel yang dipilih secaraa acak untuk setiap satuan percobaan. Beberapa variabel yang diamati pada data primer caisim adalah sebagai berikut:

a. Karakteristik agronomi, yang meliputi daya berkecambah benih di persemaian, tinggi tanaman, jumlah daun per tanaman, panjang daun, diameter tajuk, diameter batang terbawah.

b. Pemanenan, meliputi waktu panen, cara panen, alat panen, kriteria panen dan hasil panen. Ketika panen juga dilakukan pengamatan pada bobot basah per tanaman, bobot layak jual (tanpa akar), bobot daun tidak layak jual.

c. Penanganan pasca panen, meliputi pengangkutan, pembersihan, penyortiran, pengkelasan, pengemasan, dan penyimpanan.

Sumber data sekunder diperoleh dari berbagai macam literatur seperti buku, skripsi, jurnal, prosiding, internet, serta literatur lain yang terkait. Data primer yang diperoleh kemudian diolah menggunakan uji $\mathrm{F}$ pada taraf $\alpha 5 \%$ dan pada hasil yang memberikan pengaruh nyata, dilanjutkan dengan uji Duncan's Multiple Range Test (DMRT) pada taraf $\alpha 5 \%$.

\section{HASIL DAN PEMBAHASAN}

Budidaya sayuran organik secara umum di YBSB meliputi proses pembenihan, pembibitan, persiapan lahan, penanaman, pemeliharaan, panen dan pascapanen. Dalam kegiatan penelitian ini penulis mengambil aspek khusus pemeliharaan yaitu pemupukan. Selain pupuk dasar yang digunakan di awal persiapan lahan, di YBSB juga menggunakan pupuk organik cair (POC) yang dapat berasal dari air resapan kompos atau urin kelinci. Pupuk organik cair resapan kompos berasal dari air resapan hasil penyiraman saat pematangan pupuk kandang yang dilakukan setiap harinya. Aplikasi POC resapan kompos ini dapat diaplikasikan langsung ke tanaman atau dapat juga diencerkan terlebih dahulu dengan menambahkan air. Pada kegiatan penelitian ini penulis membuat dan menggunakan POC urin kelinci dengan tujuan untuk meningkatkan pertumbuhan dan hasil produksi tanaman sehingga dapat mempercepat umur panen caisim. Hasil sidik ragam peubah vegetatif caisim yang diamati disajikan pada Tabel 2.

Nilai koefisien keragam (KK) dari seluruh peubah yang diamati berada pada rentang 2.437 hingga $18.69 \%$, hal ini menunjukkan bahwa koefisien keragaman masih berada pada kisaran yang normal. Koefisien keragaman merupakan besaran yang digunakan untuk mengukur seberapa besar tingkat ketepatan dari percobaan yang dilakukan. Nilai koefisien keragaman yang semakin rendah menunjukkan bahwa keterandalan percobaan semakin tinggi (Gomez dan Gomez, 1995).

Berdasarkan tabel sidik ragam uji $\mathrm{F}$ pada taraf 5\%, perlakuan aplikasi POC urin kelinci pada 1 MST secara nyata meningkatkan pertumbuhan vegetatif tanaman caisim yaitu jumlah daun, lebar daun, dan diameter batang. Pada saat tanaman caisim umur 3 MST, aplikasi POC urin kelinci sangat nyata meningkatkan lebar daun dan diameter batang. 
Tabel 2. Hasil rekapitulasi sidik ragam komoditas caisim

\begin{tabular}{|c|c|c|c|c|}
\hline Peubah & $\begin{array}{l}\text { Umur } \\
\text { (MST) }\end{array}$ & KT & $\operatorname{Pr}>F$ & $\mathrm{KK}(\%)$ \\
\hline \multirow[t]{2}{*}{$\begin{array}{l}\text { Tinggi } \\
\text { tanaman }\end{array}$} & 1 & 1.729 & $5.2700 .0405^{*}$ & 3.433 \\
\hline & 2 & 4.491 & $3.2100 .1044 \mathrm{tn}$ & 4.207 \\
\hline Panjang daun & 3 & 11.228 & $2.7200 .1376 \mathrm{tn}$ & 6.527 \\
\hline \multirow[t]{2}{*}{ Jumlah daun } & 1 & 0.126 & $1.5100 .3045 \mathrm{tn}$ & 4.844 \\
\hline & 2 & 0.303 & $6.6500 .0246 *$ & 2.437 \\
\hline \multirow[t]{3}{*}{$\begin{array}{l}\text { Diameter } \\
\text { daun }\end{array}$} & 1 & 0.606 & $13.1500 .0048 * *$ & 3.399 \\
\hline & 2 & 1.635 & $3.8800 .0744 \mathrm{tn}$ & 5.454 \\
\hline & 3 & 4.263 & $12.5000 .0054 * *$ & 4.161 \\
\hline \multirow{4}{*}{$\begin{array}{l}\text { Diameter } \\
\text { batang } \\
\text { terbawah }\end{array}$} & 1 & & & \\
\hline & & 0.176 & $6.7700 .0236 *$ & 5.789 \\
\hline & 2 & 0.816 & $9.5400 .0106^{*}$ & 4.321 \\
\hline & 3 & 3.898 & $17.3900 .0023 * *$ & 4.889 \\
\hline \multirow{3}{*}{$\begin{array}{l}\text { Bobot basah } \\
\text { per tanaman } \\
\text { Bobot layak } \\
\text { jual per } \\
\text { tanaman } \\
\text { Bobot daun } \\
\text { tidak layak } \\
\text { jual per } \\
\text { satuan } \\
\text { percobaan }\end{array}$} & 3 & 1239.167 & $6.1400 .0293 *$ & 15.405 \\
\hline & 3 & 883.361 & $4.5800 .0538 \mathrm{tn}$ & 18.693 \\
\hline & 3 & 1381.513 & $4.850 \quad 0.0482 *$ & 16.596 \\
\hline Keterangan: & $\begin{array}{l}=\mathrm{b} \\
1 \% \\
5 \%\end{array}$ & $\begin{array}{l}\text { ngaruh } \\
\text { berpen } \\
=\quad \text { tida }\end{array}$ & $\begin{array}{l}\text { angat nyata pa } \\
\text { aruh nyata pac } \\
\text { berpengaruh }\end{array}$ & $\begin{array}{l}\text { da taraf } \\
\text { da taraf } \\
\text { nyata }\end{array}$ \\
\hline
\end{tabular}

Hal ini didukung oleh pernyataan Wijaya (2008) bahwa kebutuhan unsur hara tanaman yang terpenuhi dapat merangsang pertumbuhan daun baru. Penambahan nitrogen pada tanaman dapat mendorong pertumbuhan organ-organ yang berkaitan dengan fotosintesis (daun). Sebagai akibatnya, tanaman yang cukup mendapat suplai nitrogen akan membentuk daun yang memiliki helaian lebih luas dengan kandungan klorofil yang lebih tinggi, sehingga tanaman mampu menghasilkan karbohidrat (asimilat) dalam jumlah yang tinggi untuk menopang pertumbuhan vegetatif.

Aplikasi pupuk organik cair urin kelinci tidak berpengaruh nyata terhadap tinggi dan panjang daun tanaman caisim. Pada saat tanaman caisim berumur 1 MST, pertumbuhan tinggi tanaman caisim menunjukkan perbedaan nyata, akan tetapi ketika umur 2 MST atau 1 minggu setelah aplikasi pertumbuhan tinggi tanaman caisim tidak berbeda nyata. Hal ini disebabkan oleh kandungan unsur hara makro pada POC urin yang digunakan yang tergolong rendah yaitu

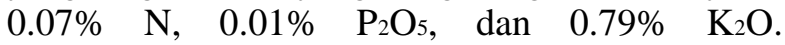
Persyaratan teknis minimal POC telah ditetapkan dalam Peraturan Menteri Pertanian Nomor 70/Permentan/SR.140/10/2011 tentang pupuk organik, pupuk hayati dan pembenahan bahwa kandungan unsur $\mathrm{N}, \mathrm{P}_{2} \mathrm{O}_{5}$ dan $\mathrm{K}_{2} \mathrm{O}$ masing-masing berkisar antara 3-6\%. Kekurangan unsur nitrogen menyebabkan terganggunya pertumbuhan tinggi dan panjang daun tanaman caisim.

Di samping itu hal ini juga disebabkan karena tanaman caisim terserang penyakit akar gada (clubroot) yang diakibatkan oleh serangan jamur Plasmodiophora brassicae.

Tabel 3. Nilai tengah perlakuan konsentrasi POC komoditas caisim

\begin{tabular}{lcrrrr}
\hline Peubah & $\begin{array}{c}\text { Umur } \\
\text { (MST) }\end{array}$ & Kontrol & $\begin{array}{r}\text { Konsentrasi } \\
\text { POC 5\% }\end{array}$ & $\begin{array}{r}\text { Konsentrasi } \\
\text { POC 10\% }\end{array}$ & $\begin{array}{r}\text { Konsentrasi } \\
\text { POC 15\% }\end{array}$ \\
\hline Tinggi tanaman (cm) & 1 & $15.84 \mathrm{~b}$ & $16.65 \mathrm{ab}$ & $16.55 \mathrm{ab}$ & $17.68 \mathrm{a}$ \\
& 2 & $26.42 \mathrm{~b}$ & $29.11 \mathrm{a}$ & $28.06 \mathrm{ab}$ & $28.89 \mathrm{a}$ \\
Panjang daun (cm) & 3 & $28.60 \mathrm{~b}$ & $30.78 \mathrm{ab}$ & $33.01 \mathrm{a}$ & $32.21 \mathrm{ab}$ \\
Jumlah daun (helai) & 1 & $5.70 \mathrm{a}$ & $6.20 \mathrm{a}$ & $5.93 \mathrm{a}$ & $5.97 \mathrm{a}$ \\
& 2 & $8.30 \mathrm{~b}$ & $8.86 \mathrm{a}$ & $9.03 \mathrm{a}$ & $8.83 \mathrm{a}$ \\
Lebar daun (cm) & 1 & $5.78 \mathrm{~b}$ & $6.56 \mathrm{a}$ & $6.13 \mathrm{~b}$ & $6.78 \mathrm{a}$ \\
& 2 & $10.82 \mathrm{~b}$ & $12.15 \mathrm{a}$ & $12.43 \mathrm{a}$ & $12.23 \mathrm{a}$ \\
& 3 & $12.52 \mathrm{c}$ & $13.99 \mathrm{~b}$ & $15.42 \mathrm{a}$ & $14.20 \mathrm{~b}$ \\
Diameter batang (mm) & 1 & $2.55 \mathrm{~b}$ & $2.69 \mathrm{~b}$ & $2.77 \mathrm{~b}$ & $3.12 \mathrm{a}$ \\
& 2 & $6.01 \mathrm{~b}$ & $7.01 \mathrm{a}$ & $6.86 \mathrm{a}$ & $7.18 \mathrm{a}$ \\
Bobot basah per tanaman (g) & 3 & $8.10 \mathrm{c}$ & $9.62 \mathrm{~b}$ & $10.66 \mathrm{a}$ & $10.35 \mathrm{ab}$ \\
Bobot layak jual per tanaman & 3 & $66.59 \mathrm{~b}$ & $87.03 \mathrm{ab}$ & $113.99 \mathrm{a}$ & $101.23 \mathrm{a}$ \\
(g) & 3 & $53.64 \mathrm{~b}$ & $67.75 \mathrm{ab}$ & $92.73 \mathrm{a}$ & $82.91 \mathrm{a}$ \\
Bobot daun tidak layak jual per & 3 & $70.57 \mathrm{~b}$ & $112.73 \mathrm{a}$ & $118.37 \mathrm{a}$ & $105.27 \mathrm{a}$ \\
satuan percobaan (g) & & & & \\
\hline Keran
\end{tabular}

Keterangan: Angka-angka pada baris yang sama dan diikuti oleh huruf kecil yang sama menunjukkan nilai yang berbeda tidak nyata dalam uji DMRT pada taraf a $5 \%$. Satuan percobaan berukuran $2.5 \mathrm{~m}^{2}$ dengan populasi caisim 36 tanaman dan selada merah 20 tanaman. 
Tanaman yang terserang akar gada terlihat segar di pagi hari, namun layu pada siang harinya. Menurut Semangun (1989), tingkat produksi sayuran yang tergolong famili brassicae seringkali dipengaruhi oleh serangan patogen $P$. brassicae yang menyebabkan akar tanaman membengkak, sehingga mengganggu translokasi unsur hara dan air. Keadaan demikian menyebabkan pertumbuhan tanaman terhambat, tanaman menjadi kerdil lebih cepat layu, mengering, sampai akhirnya mati. Meskipun kandungan unsur hara makro di dalam POC urin kelinci tergolong rendah, namun tujuan dari pembuatan POC urin kelinci adalah memanfaatkan bahan yang tersedia di alam termasuk limbah agar dapat bermanfaat dan menunjang pertumbuhan tanaman budidaya. Hal ini didukung oleh Sutanto (2002) yang menyatakan bahwa pertanian organik sebagai suatu sistem produksi yang berasaskan daur ulang secara hayati. Daur ulang hara dapat melalui sarana limbah tanaman dan ternak, serta limbah lainnya yang mampu memperbaiki status kesuburan dan struktur tanah.

Faktor aplikasi POC urin kelinci nyata meningkatkan pada hampir seluruh peubah pengamatan perlu dijelaskan dengan membandingkan rataan setiap taraf konsentrasi. Perbandingan nilai rataan taraf konsentrasi diutamakan untuk melihat perbedaan dengan kontrol. Hasil rekapitulasi nilai tengah nilai tengah konsentrasi yang diuji menggunakan uji DMRT dengan taraf nyata $\alpha 5 \%$ terdapat pada Tabel 3 . Nilai tengah ketiga konsentrasi menunjukkan perbedaan nyata dibandingkan dengan kontrol pada keseluruhan peubah vegetatif tanaman caisim yang diamatiKonsentrasi pemberian POC urin kelinci $10 \%$ nyata meningkatkan pertumbuhan jumlah caisim. Jika dibandingkan dengan kontrol, konsentrasi POC urin kelinci 10\% mampu meningkatkan jumlah daun $8.79 \%$ pada saat tanaman caisim berumur 2 MST. Hal ini didukung oleh Setiyowati (2010) yang menyatakan bahwa pemberian pupuk organik cair dengan kandungan unsur hara lengkap akan memacu fotosintesis dan hasilnya yang berupa karbohidrat akan ditransport ke seluruh bagian organ tanaman.

Lebar daun caisim pada 2 MST tidak menunjukkan perbedaan yang nyata, namun pada saat caisim berumur 3 MST pertumbuhan lebar daun nyata meningkat $23.16 \%$ dibandingkan kontrol. Kandungan hara yang cukup tersedia akan membuat luas daun suatu tanaman semakin tinggi, dimana sebagian besar asimilat dialokasikan untuk pembentukan daun yang mengakibatkan luas daun bertambah (Lakitan, 2012). Zentmeyer (1963) dalam Herdian (2000) menambahkan patogen tanah dapat dikendalikan secara biologi dengan memanipulasi lingkungan tanah, yaitu dengan menambahkan bahan organik atau sisa jaringan tanaman ke dalam tanah. Penyakit akar gada yang menyerang caisim pada umur 2 MST dapat dikendalikan dengan adanya aplikasi POC urin kelinci. Hal ini didukung oleh pernyataan Baker dan Cook, (1983) yang mengatakan bahwa penambahan bahan organik dapat merangsang pertumbuhan dan meningkatkan aktivitas mikroba tanah dan dapat mengurangi aktivitas saprofitik dari patogen. Menurut Hadi, Suseno dan Sutakaria 1976, penambahan bahan organik ke dalam tanah mengakibatkan terjadinya antagonism, antibiosis, dan kompetisi dari jasad renik yang dapat merugikan patogen.

Pada peubah diameter batang, perlakuan pemberian POC urin kelinci 10\% menunjukkan peningkatan $55.39 \%$ dari umur 2 ke 3 minggu setelah tanam. Nilai rataan tengah ketiga konsentrasi menunjukkan selang yang cukup jauh dengan tanaman kontrol. Menurut Setiawan (2007), pupuk cair mengandung unsur-unsur hara yang dibutuhkan untuk pertumbuhan, perkembangan, dan kesehatan tanaman. Unsur-unsur itu terdiri dari nitrogen $(\mathrm{N})$, fosfor (P), dan kalium (K). Nitrogen digunakan untuk pertumbuhan tunas batang dan daun. Fosfor (P) digunakan untuk merangsang pertumbuhan akar, buah, dan biji. Sementara kalium (K) digunakan untuk meningkatkan ketahanan tanaman terhadap serangan hama dan penyakit. POC urin kelinci yang digunakan mengandung $0.79 \% \quad \mathrm{~K}_{2} \mathrm{O}$ yang mampu mempertahankan tanaman dari serangan penyakit akar gada.

Panen caisim dilakukan ketika caisim berumur 3 MST, umur caisim pada umumnya sekitar 25-30 hari setelah tanam sehingga perlakuan POC ini dapat mempercepat umur panen caisim. Bobot basah pertanaman diukur menggunakan timbangan digital ketika caisim panen pada umur 3 MST. Berdasarkan tabel sidik ragam hasil uji $\mathrm{F}$ menunjukkan bahwa aplikasi POC urin kelinci nyata meningkatkan bobot basah dan bobot daun tidak layak jual tanaman caisim. Berdasarkan hasil uji lanjut, konsentrasi POC 10\% memberikan hasil bobot basah per tanaman tertinggi yaitu dengan rataan nilai tengah $113.99 \mathrm{~g}$ atau peningkatan sebesar $71.18 \%$ dibandingkan dengan kontrol. Hasil ini didukung oleh komponen hasil dari peubah pertumbuhan vegetatif terbaik yaitu jumlah daun, panjang daun, diameter tajuk dan diameter batang terbawah. Helaian daun yang lebih banyak dan lebar serta batang yang lebih besar akan meningkatkan bobot akhir tanaman caisim. Hal ini sejalan dengan yang dikemukakan oleh Krisna (2014), bahwa ketersediaan hara yang cukup untuk pertumbuhan tanaman akan mendukung laju fotosintesis yang 
cepat dan sempurna, maka pada proses pembentukan karbohidrat, lemak dan protein juga dapat berjalan sempurna, sehingga akan diperoleh hasil akhir yang maksimal.

\section{KESIMPULAN}

Kegiatan produksi sayuran organik di YBSB secara keseluruhan telah berjalan dengan baik. Kegiatan penelitian ini mampu meningkatkan pengetahuan serta keterampilan penulis baik dari segi teknis maupun manajerial dalam budidaya sayuran organik. Target produksi yang diberikan kepada setiap kepala unit mampu meningkatkan prestasi kerja dari karyawan di lapang. Aplikasi pupuk organik cair dari urin kelinci nyata meningkatkan pertumbuhan dan hasil komoditas caisim. Dari keseluruhan peubah yang diamati, konsentrasi POC $10 \%$ adalah konsentrasi terbaik untuk diaplikasikan pada tanaman caisim. Perlakuan konsentrasi POC 10\% menghasilkan rataan nilai tengah bobot layak jual tertinggi dengan persentase peningkatan sebesar $72.87 \%$ sehingga dapat dijadikan sebagai pilihan terbaik karena menguntungkan dari segi ekonomi.

\section{DAFTAR PUSTAKA}

[AOI] Aliansi Organik Indonesia. 2013. Statistik pertanian organik Indonesia. www.organikindonesia.org [11 Desember 2017].

Baker, K.F., R.J. Cook. 1983. Nature and Practice of Biologycal Control of Plant Pathogens. The American Phytophatologycal Society, St. Paul, Minnesota.

[Depkes] Departemen Kesehatan. 2017. Statistik konsumsi pangan 2015. http://gizi.depkes.go.id/wpcontent/uploads/2017/01/Paparan-BPS-

Konsumsi-Buah-Dan-Sayur.pdf [25 April 2018].

Gomez, K.A., A.A. Gomez. 1995. Prosedur Statistik untuk Penelitian Pertanian, Edisi Kedua. Sjamsuddin, E., J.S. Baharsjah, penerjemah. UI Press, Jakarta. Terjemahan dari: Statistikal Procedures for Agricultural Research.

Hadi, S., R. Suseno, J. Sutakaria. 1975. Patogen Tanaman dalam Tanah dan Perkembangan Penyakit. Fakultas Pertanian IPB, Bogor.
Herdian, A. 2000. Pengaruh mulsa, sistem tanam tumpangsari dan pengaturan $\mathrm{pH}$ tanah terhadap penyakit akar gada (Plasmodiophora brassicae Wor.) pada tanaman kailan (Brassica oleracea var acephala DC.). [Skripsi]. Institut Pertanian Bogor. Bogor.

Inawati, L. 2011. Manajer Mutu dan Akses Pasar Aliansi Organis Indonesia (AOI), semiloka Memajukan Pertanian Organis di Indonesia: Peluang dan Tantangan ke Depan. Yayasan Bina Sarana Bakti. Bogor.

Indrakusuma. 2000. Proposal Pupuk Organik Cair Supra Alam Lestari. PT Surya Pratama Alam. Yogyakarta.

Krisna. 2014. Respon pertumbuhan dan hasil tanaman jagung (Zea mays L.) terhadap pemberian pupuk organik cair ampas nilam. Dalam Rosdiana.2015. Pertumbuhan tanaman pakcoy setelah pemberianpupuk urin kelinci. J.Matematika, Saint dan Teknologi. 16(1):1-8.

Lakitan. 2012. Dasar-Dasar Fisiologi Tumbuhan. Raja Grafindo Persada, Jakarta, ID.

Maspary. 2011. Cara mudah fermentasi urin kelinci untuk pupuk organik cair. http://gerbangpertanian.com/2010/04/caramudah-fermentasi-urin-kelinci-untuk.html. [15 Maret 2018].

[Kementan] Peraturan Menteri Pertanian No.70/Permentan/SR.140/10/2011. Pupuk Organik, Pupuk Hayati, dan Pembenahan Tanah. Kementan, Jakarta.

Rukmana, R. 1994. Bertanam Petsai dan Sawi. Kanisius. Yogyakarta.

Semangun, H. 1989. Penyakit-penyakit Tanaman Hortikultura di Indonesia. Gadjah Mada University Press, Yogyakarta.

Setiawan, A.I. 2007. Memanfaatkan Kotoran Ternak. Penebar Swadaya, Jakarta.

Setiyowati, S. Haryanti, R. B. Hastuti. 2010. Pengaruh perbedaan konsentrasi pupuk organik cair terhadap produksi bawang merah (Allium ascalonicum L). J. Bioma. 12(2):44-48.

Sutanto, R. 2002. Pertanian Organik Menuju Pertanian Alternatif dan Berkelanjutan. Kanisius, Yogyakarta.

Suwandi, N. Nurtika. 1987. Pengaruh pupuk biokimia Sari Humus pada tanaman kubis. Buletin Penelitian Hortikultura 15(20):213218.

Wijaya, K.A. 2008. Nutrisi Tanaman sebagai Penentu Kualitas Hasil dan Resistensi Alami Tanaman. Prestasi Publika Publisher, Jakarta. 